\title{
Targeting the Local: Policing Clandestine Methamphetamine Production in a Rural US Community
}

William Garriott

\section{Introduction}

Methamphetamine ("meth") is a global problem. According to the United Nations Office of Drugs and Crime, amphetamine-type stimulants (of which methamphetamine is one) are the second most used category of drug in the world. Globally, more people use amphetamine-type stimulants than use heroin, cocaine, or ecstasy. ${ }^{1}$ A unique feature of methamphetamine is that it does not need to be imported: methamphetamine may be produced locally from chemicals that until recently were legal and widely available, using "recipes" available on the Internet. In the United States, commonly used chemicals include ephedrine/ pseudoephedrine (extracted from cold medications and diet pills), anhydrous ammonia, lithium (extracted from batteries), sodium hydroxide (lye), and toluene (available as paint thinner or Coleman fuel). ${ }^{2}$ Though methamphetamine has been available in the United States for the past century, the increased visibility of domestic production has amplified the sense of urgency surrounding the problem, particularly in rural areas, where it is more common.

Clandestine methamphetamine production in homemade "meth labs" has been at the centre of anti-methamphetamine legislation passed over the last decade in the United States, including the federal Combat Methamphetamine Epidemic Act, which was passed as part of the renewed USA PATRIOT Act in $2006 .{ }^{4}$ Like similar state legislation, this act created

* Earlier versions of this paper were presented at the University of Chicago and at the 2009 Annual Meeting of the Law and Society Association. I thank all who provided feedback, especially Summerson Carr, Jessica Cattalino, Catherine Fennell, Averill Leslie, Jason Pine, Lisa Pruitt, and Ralph Weisheit. I would also like to thank Dawn Moore, Sue Gemmell, Mariana Valverde, and three anonymous reviewers for the Canadian Journal of Law and Society for their comments and support. Special thanks to João Biehl, Carol Greenhouse, James Boon, and Lawrence Rosen, who provided feedback on earlier drafts. Above all, my sincerest thanks to the residents of Baker County who opened their lives to me and made this research possible.

1 UN Office on Drugs and Crime, World Drug Report (Vienna: United Nations, 2008), 5.

2 R. Weisheit, "Making Methamphetamine," Southern Rural Sociology 23, 2 (2008), 85.

3 Ibid., 78; R. Weisheit and W.L. White, Methamphetamine: Its History, Pharmacology, and Treatment (Center City, MN: Hazelden, 2009); F. Owen, No Speed Limit: The Highs and Lows of Meth (New York: St. Martin's Press, 2007); J. Pine, "Economy of Speed: The New Narco-Capitalism," Public Culture 19, 2 (2007).

4 Combat Methamphetamine Epidemic Act, Title VII of USA PATRIOT Improvement and Reauthorization Act, Pub. L. No. 109-177, 120 Stat. 192 (2006).

Canadian Journal of Law and Society / Revue Canadienne Droit et Société, 2010, Volume 25 , no. 1 , pp. $1-19$ 


\section{William Garriott}

new regulations for chemicals commonly used in the methamphetamine production process. One key requirement forced over-the-counter cold medications containing pseudoephedrine (such as Sudafed) behind the pharmacy counter. To purchase these medications, customers must now show valid ID and sign a state registry that records the names of purchasers and limits the amount they purchase to 3.6 grams per day and 9 grams per month. Similar regulations have been placed on other precursor chemicals such as anhydrous ammonia.

I am not concerned here with evaluating the effectiveness of this strategy. ${ }^{6}$ Rather, in this article I examine the impact the strategy has had on the exercise of police power in a rural community affected by methamphetamine. Taking an ethnographic approach, I argue that the focus on clandestine methamphetamine production has expanded the power and responsibility of police beyond the formal domains of law enforcement. ${ }^{7}$ Under the anti-meth legislation, previously benign objects such as cold medicine, batteries, and drain cleaner have been re-signified as objects with criminal potential, which residents of rural communities are called upon to police. As a result, citizens who were previously uninvolved in drug enforcement have been incorporated into the process through the reimagining of the local landscape in terms of police power.

What follows is part of a larger project examining the impact of methamphetamine on a cluster of rural communities in the Appalachian region of the United States. Between 2006 and 2007, I conducted 12 months of ethnographic fieldwork in a five-county area of rural West Virginia where, at that time, methamphetamine was an emerging concern. To preserve the anonymity of the area and to protect those with whom I worked, I write about this area as a single county, which I call Baker County.

Methodologically, I gathered material in three primary ways: (1) through analysis of all known methamphetamine-related criminal cases in the area; (2) through regular court attendance in each of the five counties; (3) through interviews with those closest to the local meth situation, including those who (a) worked in a profession dealing with meth, (b) participated in community action groups focused on meth, or (c) had been personally affected by meth; and (4) by participating as fully as possible in the life of the community. I sang in the community choir; served as a judge in the social studies fair; assisted with Bingo night at the nursing home; and attended

\footnotetext{
Weisheit, "Making Methamphetamine," 87.

It should be noted, however, that since this type of legislation began going into effect, the number of meth-lab incidents in the United States has dropped from 17,356 in 2004 to 6,783 in 2008. See Drug Enforcement Agency [DEA], Maps of Methamphetamine Lab Incidents (1999-2008), http://www.usdoj.gov/dea/concer/map_lab_seizures.html; for discussion see Weisheit, "Making Methamphetamine."

7 Of course, law enforcement is only one mode of the police power of the state. Thus, as I discuss it here, what is expanding is this particular mode of the police power, not the police power per se.

8 All names of people and places have been changed to protect the anonymity of those involved in my research.
} 
major social events, including hymn sings, county fairs, and church luncheons. This participation provided a crucial perspective on the wider socio-cultural context of the problem.

\section{Making Methamphetamine}

"I've seen what drugs can do to a lot of people." Justin Stokes sat across the table from me. I continued to sip my coffee, while he (and the waitress) had long forgotten about his empty glass of iced tea. Justin had been convicted of multiple counts of possession of methamphetamine with intent to deliver three years ago. He had served two years in the regional jail and was completing his sentence on probation. A high school friend of Justin's had introduced us when he heard I was doing research on methamphetamine.

Justin lived alone in a small farmhouse on top of the mountain that stands between the county seat of Meadville and the small town of Dove. For reasons he never made clear, Justin had no telephone. To reach him, I had to call his cousin, who would then walk next door to see if Justin was home. On my third attempt, I reached him, and he agreed to a meeting. Justin suggested we meet at Annie's, the restaurant attached to the bowling alley in downtown Meadville.

Justin was already sitting on a bench outside the restaurant when I arrived, his short, dark hair mostly covered by his baseball cap. Justin was stocky, though he explained as we entered the restaurant that he actually weighed 50 pounds less than he had a year ago - a fact he attributed to the healthy lifestyle he'd adopted since his release from jail but others, including his probation officer and his ex-wife, saw as a clear sign that he was again using meth. Justin dismissed these suspicions as the standard gossip that had always followed him in this town, the kind of talk that had made it a difficult place for him to live even before he became involved with meth.

I was somewhat surprised that Justin had chosen Annie's as a meeting place. Annie's was the most public place in town; according to locals, half the town's population ate at least one meal a day there. My surprise at Justin's choice grew as the waitress slowly approached our table. I sensed a coldness in her demeanour, something I hadn't sensed before when I'd been there alone (I typically treated myself to a piece of their blackberry cobbler after a long day poring through court documents or sitting in on court proceedings). I assumed she knew who Justin was and was probably wondering who I was, other than a stranger meeting publicly with one of the most notorious drug dealers in town. I would later learn that the waitress's son, John, had also been sent to jail for selling meth. Indeed, Justin and John were part of the same string of arrests, which came after a Federal Drug Task Force began to focus on the area.

Justin spoke in hushed tones; he smiled his crooked smile on occasion but mostly remained serious. He had been convicted of selling meth but not of producing it; he claimed, nevertheless, to have been involved with both. Indeed, he started producing meth because he refused to steal (or, worse, to 


\section{William Garriott}

"sell his body," as he'd seen others do) to maintain his habit. "After I knew how to make it [meth], it was on," he said excitedly. "I'd just go up here to the hardware store, get my stuff, come back to the house and cook it."

"Were you able to get everything you needed just at the hardware store?" I asked.

"Hardware store, Rite Aid ..." Justin replied. "I don't know if you know what it's made out of ..."

"I know basically," I said, "but I don't know specifics ..."

Justin began listing the ingredients: "Boranic acid, witch hazel, Nasonex, Sudafed; I've seen it made with ether, sulphur ..." As he spoke, he became progressively more excited, seeming to take pleasure in his own ingenuity.

Though he did not name it as such, Justin was describing the so-called Nazi method of producing methamphetamine. The folk etymology of this term holds that it was developed by Nazis during World War II to produce methamphetamine and other amphetamines consumed by the Nazi military and key officials, including, supposedly, Hitler himself. Until the advent of the new regulations limiting the sale of precursor chemicals used to produce meth, this was the most common method of production, first gaining prominence among Hells Angels and other biker gangs in the West and then going national once such recipes-which had been kept a guarded secret-were made public knowledge via the Internet. ${ }^{9}$

Here is how Donnie Grate, another local methamphetamine cook, described the production process to the prosecuting attorney of Baker County:

You take the Sudafed, pop them out of the pack, crush them and grind them, put them in a bucket. Take your batteries, peel them off and get the lithium strip out of them. Put the pills and the lithium in a bucket and pour the anhydrous on it. Then you throw Coleman to it, it will bubble like bubble a white stream of liquid. Then you take the lid off, put it in a jar. Then you take a pop bottle with tubing, three inch tubing, and then you put salt liquefier in it and smoke it. Put it in a jar and smoke that liquid. Then you filter that into another jar and get the meth out.

Recent anti-meth legislation has targeted this kind of domestic production by heightening regulations on chemicals used in the cooking process. Though new, this legislation is part of a long history of attempts to regulate amphetamines and related precursor chemicals, which have moved in and out of formal legality for decades. ${ }^{10}$ Whereas previous efforts focused largely on the national and international flows of bulk supplies, the recent legislation foregrounds local intervention at the point of sale. This has required the involvement of a wider range of individuals at the local level to enforce the regulations.

9 Owen, No Speed Limit.

10 R. Weisheit and J. Fuller, "Methamphetamines in the Heartland: A Review and Initial Exploration," Journal of Crime and Justice 27 (2004). 
Of course, not every social actor carries the same responsibility to police the methamphetamine problem. While some individuals I spoke to were required by law to enforce new regulations on chemicals used to make methamphetamine, others were simply encouraged to be more attentive to signs of meth production and use. Pharmacists, for instance, were given a very specific set of responsibilities for policing the circulation of medications containing pseudoephedrine- the key ingredient in the "Nazi method." These included checking customers for appropriate ID, monitoring the state registry, and evaluating whether the purchaser was a "legitimate" customer or not (i.e., does the person have a cold, or is he or she looking to make meth?). These are responsibilities that pharmacists are legally required to perform as a result of new legislation. A similar set of responsibilities has been placed on retail clerks at businesses where products used in the methamphetamine production process are sold, either as a result of the new legal regulations on these substances or as businesses implement their own policies to discourage the illicit use of the products.

At the other end of the spectrum are those who are simply encouraged to be more attentive to the signs of methamphetamine as they go about their routine social activities and commitments. For instance, local volunteers participating in the Adopt-A-Highway program were given information by program coordinators on the signs of methamphetamine production, including a list of objects - such as coffee filters, glass bottles, and coolers - that volunteers might encounter while picking up litter on the side of the highway. Participants were instructed to contact local police should suspicious objects be discovered. Similar information was given to state road workers, hunters, and others. While it did not formally require participants to engage in the policing of methamphetamine, such information did encourage them to be mindful of the signs of illicit meth production and to incorporate such mindfulness into their everyday routines. The information also instructed participants to contact police in the event that suspicious objects were encountered. In this way, it complemented the formal requirements placed on pharmacists and others by anti-methamphetamine legislation.

This combination of formal and informal strategies enabled the broad mobilization of the local population around the methamphetamine problem. But not everyone was mobilized in the same way. Rather, what can be seen are scales of participation in which residents were variously encouraged and/or required to police the local landscape for signs of methamphetamine. In this context, the common element was not the degree of involvement or the kind of participation but the emphasis on reimagining the local landscape in terms of methamphetamine and thus of police power.

11 It should be noted that this approach to the policing of methamphetamine is not simply the product of regulatory decisions. The specific materiality of methamphetamine is at the heart of the process as well. Indeed, the expanded field of police practice I document here would not have unfolded in quite the same way were it not for the fact that meth can be produced through everyday, licit commodities available for other purposes. 


\section{William Garriott}

That the police power of the state has been channelled through the local is hardly surprising. In the United States, much of the "heavy lifting" involved in criminal justice takes place in local jurisdictions." ${ }^{12}$ This reflects what Lawrence Friedman has called the "major structural contradiction" inherent in the US criminal justice system: "The causes of crime, the reach of crime, the reality of crime -all these are national in scale and scope. Criminal justice, on the other hand, is as local as local gets."13 Indeed, as Markus Dubber and Mariana Valverde have observed, there is a strong tendency in the US context to delegate the state's police power to municipalities. "In fact," they write, " the police power' is sometimes imagined as essentially local.,"14

But this arrangement affects the constitution of "the local" as much as the administration of police power. ${ }^{15}$ That is, just as there is a tendency in US law to imagine police power in local terms, so there is also a tendency to imagine the local in terms of police power. This is evident in the approach taken toward clandestine methamphetamine production. To police this problem, residents of rural communities have been equipped with a new field of vision, a new way of perceiving the local landscape, centred around methamphetamine. Immanent in this new field of vision is a set of responsibilities, variously distributed, to police the local landscape for signs of meth. In this way, the anti-meth legislation has re-mapped the "juridical field" of local communities, generating a distinct "legal habitus" centred on the policing of clandestine methamphetamine production. ${ }^{16}$

This habitus is based not on struggle, competition, and conflict (as in Pierre Bourdieu's account) but on suspicion, apprehension, and-in certain cases - a sense of loss. ${ }^{17}$ Indeed, though some in Baker County participated in the policing of methamphetamine enthusiastically, others did so with reluctance, indifferently, or at significant personal cost, including the loss of the local as they imagined it. For these individuals, knowledge of clandestine

12 S. Scheingold, The Politics of Street Crime: Criminal Process and Cultural Obsession (Philadelphia: Temple University Press, 1991).

13 L.M. Friedman, Crime and Punishment in American History (New York: Basic Books, 1993), 461.

14 M.D. Dubber and M. Valverde, "Introduction: Perspectives on the Power and Science of Police," in The New Police Science: The Police Power in Domestic and International Governance, ed. M.D. Dubber and M. Valverde (Stanford, CA: Stanford University Press, 2006), 6.

15 As I use the term, "local" refers both to the physical locale (in this case, Baker County) and to the social relations situated within it, particularly those so-called everyday or ordinary social relations. Juridical constructions of the local in terms of jurisdiction are part of this as well. See, for example, H. Varenne, Americans Together: Structured Diversity in an American Town (New York: Teachers College Press, 1977); C. Geertz, Local Knowledge: Further Essays in Interpretive Anthropology (New York: Basic Books, 2000); V. Das, Life and Words: Violence and the Descent into the Ordinary (Berkeley: University of California Press, 2007). No categorical distinction between state personnel / state power and "the local" should be assumed; Any such distinctions are themselves an effect of power relations. See T. Mitchell, "The Limits of the State: Beyond Statist Approaches and Their Critics," American Political Science Review 85, 1 (1991), 77-96.

16 Here I draw on Hagan and Levi's reading of Bourdieu. See J. Hagan and R. Levi, "Crimes of War and the Force of Law," Social Forces 83, 4 (2005), 1499-534. Ibid., 1502-3. 
methamphetamine production was a "poisonous knowledge" that revealed an illicit potential in the community of which they would have preferred to remain unaware. ${ }^{18}$ Thus the new legal habitus ushered in by anti-meth efforts was occupied differently by different actors, even as it expanded the range of individuals involved in the policing process.

\section{Policing at Work, Work as Policing}

Many of the new regulations on precursor chemicals regulate their circulation at point of sale. This means that policing these chemicals is now part of the daily work routine for employees of businesses where such chemicals are sold. Pharmacists are a key example. As mentioned above, pharmacists have been given significant responsibilities under the new anti-meth legislation, which effectively created a new category of medications: over-thecounter medications that are kept behind the pharmacy counter. In addition to maintaining the state registry that records the names of those purchasing products containing ephedrine or pseudoephedrine, pharmacists must now limit the amount of medication individual customers buy and do triage work in distinguishing legitimate from illegitimate customers.

I went often to the pharmacy in town. It was a locally owned operation and, as a business, functioned more like a general store. In addition to filling the majority of prescriptions for local residents-outdoing the local chain stores, including Wal-Mart-the store offered a small selection of books and magazines, groceries, tools, kitschy West Virginia souvenirs, home décor, and clothing.

The family who owned the store-the Mackies-were friendly but generally reserved. They would share anecdotes with me about experiences they had with "druggies," but they were reluctant to reveal much about the inner workings of their business. This was understandable: as the primary purveyor of medications in the town, they were entrusted with knowledge about the health of the community on both an aggregate and an individual scale. If they were guarded, it was because they were aware of the sensitivity of the information they possessed and took their role as stewards of this information very seriously.

The Mackies enforced the new regulations as they were required to dothough Jerry Mackie expressed doubts that the new laws would have much effect. They posted a sign informing customers that all medications containing ephedrine or pseudoephedrine were now held behind the pharmacy counter. Those who wished to purchase one of these products were asked to show ID and to sign the state registry. Most of these sales were benign, and so the Mackies were not particularly moved by the new requirements. Indeed, they were, in many ways, already involved in this kind of triage work, but in a different way.

18 V. Das, "The Act of Witnessing: Violence, Poisonous Knowledge and Subjectivity," in Violence and Subjectivity, ed. V. Das, A. Kleinman, M. Ramphele, and P. Reynolds (Berkeley: University of California Press, 2000), 205-25. 


\section{William Garriott}

I often saw Dustin Mackie-Jerry Mackie's son-out in town. He was quiet, but often commented when the pharmacy had noticed someone trying to get access to drugs illegally. For instance, he told me about a woman who came in with a prescription that had obviously been forged; the Mackies knew it had been forged because they were very familiar with both the signatures and the prescribing practices of the only two doctors in town. "Even if I'd believed the signature," Dustin explained, "there's no way Dr. Jenkins would have prescribed as much Vicodin as that prescription said." Thus, for Dustin, this local knowledge, acquired through long-term relationships, was superior to the state's bureaucratic measures as a method of monitoring the illicit acquisition of prescription drugs.

And yet, in other areas, the state was finding ways to put this local knowledge to work. One county sheriff told me about an old friend who ran one of the many "country stores" that dot the rural landscape in his jurisdiction, providing the groceries and convenience items that gas stations stock in more urban areas. The sheriff had gone around to the owners of these stores to warn them that there were people making meth in the area and to ask that they pay attention to anyone buying a lot of cold medicine, cooking fuel, or batteries or asking for anything strange, like plastic tubing. His friend looked surprised and told him about an "old boy" who had started showing up and buying all his cold pills just as quickly as he could stock them, saying he had bad allergies. The sheriff's friend thought this was strange, but he hadn't been aware of the methamphetamine problem, or of the fact that meth could be made with cold medicine and other everyday items.

But the state is not the only institutional actor restricting access to precursor chemicals. National chain stores such as Wal-Mart, Tractor Supply, and Southern States that are common in rural communities have developed their own policies that complement the new regulations contained in the legislation. I regularly went to Tractor Supply to get dog food for my two dogs; one evening I noticed a sticker on the front door that read "METH WATCH."19

"Have you been having a lot of problems with meth?" I asked the cashier as I checked out.

She was in her forties, and without even looking up at me began explaining the program. "They gave us a list of things we're supposed to watch out for," she said, wrestling the large bag of dog food over the scanner and back into my cart.

"What are you supposed to do if you see people buying those things?" I asked.

"Well, if they're buying a whole bunch of something, or if we think they might be using it to make meth, then we're supposed to sell it to them and then follow them to the parking lot and see what vehicle they get into and write down the licence-plate number."

"What do you do then?"

19 For more information on the Meth Watch program see http://www.methwatch.com/ index.aspx. 
"Well, we give their licence-plate number to the manager, and I think they call the police."

I asked her if employees at other stores were having to do the same kind of monitoring of purchases. She told me about a friend who worked at Southern States-an agricultural supply store-where workers had been asked to monitor the sale of certain chemicals that could be used in producing meth. Employees at Southern States drew directly on the their relationships with local farmers to carry out this task. The employees knew these farmers well, including the amount of each chemical they would need in a typical year. If a stranger came and started buying a lot of one of these chemicals, or if a regular customer seemed to be ordering more than should be needed over the course of a year, the employees were to notify law enforcement.

Businesses were not the only sites at which people were being asked to monitor chemicals and other things associated with methamphetamine production, however. Nor was regulation at point of sale the only means through which rural residents were being mobilized. State road workers and civic volunteers, among others, were given instructions on how to recognize the signs of a meth lab in operation, including how to distinguish garbage carelessly strewn along the highway from the remnants of a meth lab. Having such knowledge was important not only as a safety measure but also to aid law enforcement in detecting local meth producers. In this way, road workers and volunteers added a new temporality to the policing of clandestine methamphetamine production. While the retail workers' policing of precursor chemical sales was "forward looking" in its orientation, seeking to prevent clandestine methamphetamine production from taking place, the road workers' policing of meth-lab remnants was "backward looking," seeking to find meth producers after the fact. Thus the targeting of methamphetamine production enabled the expansion of police power locally in both space and time, "allowing the governance of the past to be articulated with the governance of the future.",20

Kent MacAfee, a retired army contractor who was involved with numerous volunteer organizations in the community, was enlisted in this way into the work of policing methamphetamine. Kent brought me an instruction sheet produced by the West Virginia Division of Environmental Protection that he had received while doing road clean-up as an Adopt-A-Highway volunteer. These were the instructions given to participants:

Do not pick up the following items, as they may be associated with Methamphetamine preparation:

Containers and glassware with white residue or powder

Grinders

Coffee filters

Funnels

Glass or plastic tubing

20 Dubber and Valverde, "Introduction," 4-5. 
$\mathrm{pH}$ papers

Coolers and condenser tubes

Volunteers were further wamed that

The items listed above are often found in plastic grocery store bags that have been tied shut and thrown on the side of the road. Opening the bags can result in burns, blindness and serious health problems. They may even explode.

In addition to educating volunteers on the signs of clandestine methamphetamine production, these instructions also told volunteers what to do should they encounter the remnants of a meth lab:

Leave the bags where they are and call 911. After calling 911 please report any meth lab items you find while picking up litter to the Adopt-A-Highway Program.... (original emphasis)

These instructions gave participants in the Adopt-A-Highway program a new orientation toward their work: what had previously been a benign form of volunteerism was now a potentially dangerous activity, given that the litter they were picking up might actually be remnants of a meth lab intentionally dumped by cooks. Such objects posed a direct threat to those involved, and required them to call local law enforcement if they encountered anything suspicious. Thus, knowledge of local meth production was transforming participation in the Adopt-A-Highway program by drawing attention to potential threats in the local landscape and by encouraging citizens to police the problem.

The same kind of instruction was given to state road workers. Charlie Kent, a man I met while singing in the community choir, worked for the Department of Transportation; he showed me a publication he had received informing road workers about the dangers of methamphetamine production. After presenting some general information about methamphetamine provided by the Drug Enforcement Agency (DEA), the article concluded with instructions on what road workers should look for and what they should do with respect to meth labs. This section, entitled "Road Workers Need to Be Alert," stated that,

[1]ike hunters and Adopt-a-Highway volunteers, road workers are among those likely to stumble upon a meth waste dump.

Be alert. What may initially look like harmless trash in a ditch may be lethal meth waste material.

Do not go near the material(s).

Do not touch or move anything in the area. In addition to being dangerous to yourself, disturbing the area may hinder law enforcement agencies['] efforts to trace the lab location and/or the manufacturers.

Contact your supervisor immediately. Your supervisor should contact law enforcement personnel with the exact location of the possible meth waste dump. 
Thus, state road workers have been given the same instructions and responsibilities with respect to methamphetamine as Adopt-A-Highway volunteers. However, their instructions are even more explicit in discussing state road workers' role in police work: road workers are instructed not to touch anything that might be a meth-lab remnant not only because of the threat to their safety but, more importantly, because it could interfere with law enforcement efforts to locate the cooks. For their part, then, road workers in Baker County were instructed to participate in the policing of methamphetamine through vigilance in looking for signs of meth production and through precision when reporting the location of meth-lab remnants to law enforcement.

In each case, the protocols given to pharmacists, road workers, retail clerks, and volunteers provided a new way of seeing the local landscape in terms of methamphetamine. Previously benign objects, such as a plastic bag on the side of the road or an over-the-counter cold medicine, were resignified as potential threats through their association with clandestine meth production. Furthermore, this knowledge carried with it the responsibilityat times overt, at other times implicit--to act: to engage in the work of policing on the spot and/or to provide information to local law enforcement. In this way, the range of individuals policing the methamphetamine problem was expanding as the local landscape was reimagined in terms of meth.

\section{Expanding the Field of Drug Control}

This expansion of police power was also taking place within the field of law enforcement itself. A significant group in this regard were officers of the Department of Natural Resources (DNR). These officers are in charge of monitoring state-owned land, particularly state parks and reserves; their primary duties consist of enforcing laws related to these areas, particularly those regulating hunting, fishing, camping, and so on. A typical day for a DNR officer would involve travelling through a section of state park making sure no one was hunting out of season or fishing without a licence. Methamphetamine, however, was changing this in Baker County: meth cooks' preference for secluded rural areas meant that these officers had to be on the lookout for meth production.

The first person I spoke to about these changes was a DNR officer named Matt Keezle. Matt had been an officer for nearly 10 years. An avid outdoorsman himself, he felt that working for the DNR was the closest he would ever get to hunting and fishing for a living. I met Matt through a mutual friendsomeone with whom Matt went fly-fishing on occasion.

The office of the DNR was located on an empty stretch of the highway, 20 miles from the nearest town in either direction. When I arrived, Matt was sitting in a swivel chair in front of a small desk. His receding hairline and green uniform made him seem older than he actually was. A plug of chewing tobacco bulged slightly from his lower lip, and between his legs sat a small Styrofoam cup, which he raised to his mouth occasionally to spit. 


\section{William Garriott}

When I told Matt that I was doing research on methamphetamine, he began telling me about a course he had taken a year or two earlier that all the DNR officers had been required to take. "They gave me a big folder full of information," he said, and began to search through the office to find it. "I know it's here somewhere," he assured me, rummaging through bookshelves stacked somewhat haphazardly with training manuals, file folders, and other bits of bureaucratic miscellany. I asked Matt if he had had much direct involvement with methamphetamine. He explained that the most significant thing he encountered were the remnants of meth labs that were no longer in use; by the time he found them, the cooks were usually long gone.

DNR officers had the jurisdiction and responsibility to deal with these former labs, Matt explained, but tried to avoid doing so if possible, because it was dangerous. Matt relayed the story of a local police officer who had inadvertently come upon an active meth lab and suffered either liver or lung damage (Matt couldn't remember which) as a result. There was also a "you touch it, it's yours" policy that governed jurisdictional issues among the various branches of law enforcement in the area, at least informally. Cleaning up after a meth lab was so time consuming and expensive DNR officers avoided doing it if at all possible. This reveals an important yet overlooked dimension of national efforts to stop clandestine methamphetamine production: beyond the standard bureaucratic squabbles, the costs associated with cleaning up a meth lab are significant. County governments and state agencies in rural areas such as West Virginia have limited funds for such activities, which creates a financial disincentive for them to seek out signs of meth production.

Matt finally abandoned his effort to find the folder from the meth training course and instead reached for a small shoebox on top of a nearby bookshelf. The box contained all the drug paraphernalia he had confiscated over the years, mostly homemade pipes fashioned out of everything from plastic cups to a bear-shaped honey container. Matt pulled out the empty shaft of a ballpoint pen. He had found the pen after stopping two boys in a state park whom he suspected of using drugs. Matt had not found any drugs on the boys when he looked into their car, but he noticed the pen piece on the ground after they left. Matt knew from his training that these pen pieces are often used to smoke meth; the user puts the meth on a piece of aluminum foil, holds a lighter underneath, and uses the ballpoint-pen "pipe" to smoke the meth as it rises up. Matt told me that he could have pursued the two boys but chose not to do so because he knew it would be nearly impossible to bring charges against them. Since he had not found the pipe in their possession, nor found any actual methamphetamine, the prosecuting attorney for the county probably wouldn't even have pursued the case.

The phone rang. Matt answered it, still holding the shoebox full of drug paraphernalia. "Hey," he said casually. "I'm talking to that guy I told you about who wanted to know about meth." A small smile appeared on Matt's face as he listened to the officer on the other end. "No, I didn't tell him 
about that," he said with a laugh. Matt then told the officer he would talk to him later, and hung up the phone.

"Tell me about what?" I asked.

Matt smiled sheepishly and began telling me about a recent encounter. He had been doing his normal patrol through the back roads of the national forest when he noticed a truck parked in a small clearing beneath a tree. Matt parked and approached the truck. When he got there, he found a man sitting in the truck by himself, smoking meth and masturbating. Matt chuckled again, somewhat awkwardly, and shook his head in amazement. "That isn't even the first person I've caught doing that, either," he said, and told me briefly about another man he had found likewise sitting in his truck smoking meth and using a "pocket pussy" to masturbate.

I returned Matt's sheepish smile, embarrassed both for him and for the men he had discovered. We sat in awkward silence for a moment, until a state trooper came into the office. The DNR shared the building with the state police, and the officer had come by to pick something up from his desk on his way home from work. Matt flagged the officer down as he came in and introduced me. His name was Gil McDonald. Like Matt, he was increasingly encountering meth as part of his work, including the same remnants of meth-lab production.

Gil was also seeing more meth-related activity in his patrol work. In fact, he had just been involved in an undercover drug bust of a person who was selling methamphetamine. He unlocked a drawer on his desk and pulled out a small envelope marked "Evidence." To my surprise, he unsealed the envelope and pulled out four small baggies containing a brownish crystalline substance that resembled unrefined sugar. He also pulled out a small metal tube, roughly three inches long, with a screw-off top. The meth had been in the metal tube on the person's key chain when they arrested him. Gil, too, had undergone training about methamphetamine. "That's how I knew what to look for," he said proudly.

Matt's and Gil's experiences demonstrate how methamphetamine has created a common denominator for all forms of police work. The training they received about methamphetamine, like that given to state road workers, retail clerks, and others, heightened their awareness of meth and created new responsibilities to police it. This expanded the work of drug enforcement into seemingly unrelated domains, such as daily patrols by DNR officers. While this was probably only a shift in focus for Gil, Matt was given a much more significant set of requirements with respect to policing state lands for signs of possible meth production. By his own admission, he carried out these new duties with a mix of enthusiasm and reluctance, seeking to fulfil his obligations in detecting former meth labs without creating a financial and administrative burden for the DNR. Furthermore, his range of encounters with meth users seemed a befuddling part of the job for Matt. The fact that he had arrested none of the users he encountered suggests reluctance on his part to fully assume the role of drug enforcer. Nevertheless, simply by being aware of what to look for, Matt was involved 


\section{William Garriott}

with policing methamphetamine, even when this resulted only in informal intervention.

\section{Locating the Meth Lab}

As these various cases show, efforts by federal, state, and local governments to curtail the spread of methamphetamine have expanded the range of individuals involved in police work by increasing awareness of the signs of meth production and use. Though local knowledge and conflicting professional obligations can limit these efforts, they can also provide new avenues for their implementation. This was certainly evident in the most significant meth-lab bust that occurred in Baker County. The discovery of this meth lab took place through the inadvertent deployment of local knowledge in response to the observation of suspicious activity, combined with a more professionally nuanced awareness of the (admittedly subtle) signs of meth production. This action, in turn, revealed a much deeper and more complex web of participants in the local meth trade.

In the fall of 2004, a DNR officer received an anonymous tip that someone had killed some deer out of season and was processing the hides in the cellar that stood adjacent to a small cluster of trailers in a remote part of the county. According to court documents, the DNR officer followed up on the call and later met with a deputy from the county sheriff's department to begin an investigation. The deputy and the officer drove by the building and observed what the DNR officer had earlier seen: people coming in and out of the house and rubbing their eyes. They approached the building. There was a strong chemical smell, and white smoke was pouring out, apparently coming from a plastic soda bottle near the door. On the grass they found coffee filters, paper towels, plastic tubing, and a number of large jars and other containers with lithium AA batteries that had been disabled. Through the open cellar door, they saw a yellow two- to four-gallon bucket. Inside the bucket, a white liquid substance was bubbling.

Within five hours the officers made their first arrest. The arrestee's name was Jimmy Barker, and he lived in one of the trailers. He knew about the meth lab because it was in the cellar behind his brother-in-law's trailer (his brother-in-law, Larry Messinger, was one of the other suspects). According to Jimmy, Donnie Grate, the third suspect in the case, had constructed the lab. Donnie's father lived in a trailer next door to Jimmy's father-in-law. Jimmy had seen Donnie in the cellar that morning and stopped by to say hello; he saw him tearing up batteries, mixing something in a yellow bucket, and calling for Larry to bring down the jars he'd left outside. The officers asked Jimmy if Donnie had told him he was making meth. "No, I just assumed," Jimmy replied. "I'm not real smart, but I figured it out. He was all the time talking about how he could make meth. How easy it was."

The next day, a special unit of the West Virginia State Police was called in to collect the materials surrounding the cellar. They collected the plastic soda bottle that had been emitting the white smoke, tubing containing an orangey- 
white paste (which later tested positive for hydrogen chloride), the batteries, the coffee filters, and the paper towels. Inside the cellar they found a onegallon can of Camp Fuel; a half-gallon jug of Roto Drain Opener; a three-pound box of kosher salt; a cooler containing half a gallon of an unknown liquid, with condensation on the side and smoke coming through the spout (which tested positive for ammonia); a one-gallon glass jar containing an unknown residue; and the plastic bucket and its contents. All of this was collected as evidence.

Jimmy, Larry, and Donnie were all arrested on charges of operating a clandestine drug laboratory and conspiracy to commit an offence against the state of West Virginia. Donnie waived his right to an indictment and agreed to a plea agreement with the state in which he pled guilty to the conspiracy charge; in return, the charge of operating a clandestine drug laboratory was dropped.

As a condition of the plea agreement, Donnie agreed to tell the prosecuting attorney and local police the process by which they had assembled the lab and made methamphetamine. According to Donnie, Larry Messinger's father, Andy Messinger, had come home one day with a meth recipe and instructions on how to set up and operate a lab, which he had obtained (presumably from a co-worker) at the poultry-processing plant in Virginia where he worked. Donnie agreed to show him how to make meth, while Larry and Jimmy began gathering the necessary ingredients.

Jimmy, Donnie said, developed a technique for stealing Sudafed from all the local stores that carried it. He would wear a camouflage jacket, stuff the boxes of pills in his inside pocket, remove the pills from their boxes in the store's restroom, and walk out with the pills in his jacket. Both Jimmy and Larry were involved in obtaining the anhydrous ammonia, which they took from a large tank on a dairy farm in Virginia.

Donnie revealed that Jimmy's parents actually had a longer history of making meth, which they had done secretly for at least eight years. In fact, according to Donnie, there had been significantly more meth in their trailer than was found by the police in their investigation of the meth lab just a few hundred yards away. They made it for their own use, but also to sell to friends and acquaintances at the poultry-processing plants in the area and other places in "the community." Donnie recalled a summer when he had gone to visit Jimmy and his family and saw bricks of meth just sitting in their trailer.

Donnie's story revealed an extensive network of local users and dealers who could obtain everything they needed to make methamphetamine in the local community. Indeed, Jimmy, Larry, and Donnie were all second-generation meth users and cooks; in this case, even family ties carried criminal potential. Thus, from a law-enforcement perspective, Donnie's account confirmed the insidiousness of the methamphetamine threat and legitimized efforts to raise awareness about the chemicals used in clandestine methamphetamine production. 


\section{"Where Have All the Good People Gone?"}

Policing methamphetamine through the signs of clandestine production enabled the detection of the meth lab discussed above. What began as a report of hunting out of season became, by virtue of the DNR officer's training, the detection and disruption of a local meth lab. Yet, as I have discussed above, the acquisition of such knowledge is never a straightforward operation. Matt Keezle's efforts to police methamphetamine on state lands, for instance, were complicated by the financial disincentives accompanying the clean-up of former meth production sites. Additionally, one might wonder how willing citizens will be to participate in the Adopt-A-Highway program once they know about the threats posed by methamphetamine. More significantly, however, greater awareness of the signs of methamphetamine production was, for many, an epistemic and existential burden. While it might aid in the detection of illicit producers, it also changed their everyday lives in fundamental and challenging ways.

I experienced this firsthand while attempting to arrange an interview with a state trooper who had spent two-and-a-half years working as part of a Federal Drug Task Force in the area. Most of this work had been undercover, so he was surprised to receive my call. From the beginning he was suspicious of who I was and why I was interested in methamphetamine. He was particularly curious as to how I had found his phone number. After I explained that I had been given his name and number by another police officer, and answered a series of questions about what I wanted to know and what I planned to do with the information, he eventually agreed to meet with me-but only reluctantly, and with no sense that I had eased his suspicions. "I'm not gonna run a background check on you," he said with an uneasy smile I could hear through the telephone (a statement that made me assume that he would indeed be running a background check on me). Nevertheless, he took great care in writing down my name and affiliation, and insisted that I bring two valid forms of identification to the interview, because, as he put it, "You wouldn't believe what some people will do to get some inside information."

The officer provided little in the way of new information, and by the end of the interview I was ready to write off the encounter, attributing his disposition to the suspicion and secrecy required by his profession. But as he escorted me out of his office, he began to make comments that connected his suspicions of me to his experiences with methamphetamine. In addition to witnessing the extremes to which people will go in order to satisfy their addiction, he had had to come to terms with the extensiveness of the problem in his community - the sheer number of people who used the drug or were involved in making and selling it. He found all of this very challenging, particularly as he tried to lead a normal life outside of work. "It's hard," he said, "especially when you're out with your family. I can take you to any street anywhere in the area, including the dirt roads, and show you someone who's using or selling drugs. It makes you wonder, 'Where have all the good people gone?'" 
This sentiment was one I encountered often. Many people in the community, including police officers, addiction counsellors, concemed citizens, and even addicts themselves, frequently figured their experience with methamphetamine as an experience of loss. What was being lost was a particular vision of the local community as they had once imagined it, a vision in which methamphetamine-and the problems that come with it—was not a factor. As the officer put it, "Sometimes I wish I was more naïve." Thus, while knowledge of methamphetamine was crucial to mobilizing citizens around the policing of the problem, it was also a kind of "poisonous knowledge" that residents often adopted warily. ${ }^{21}$

Bearing this epistemic burden, however, did not absolve individuals of the responsibilities that implicitly and explicitly accompanied greater awareness of clandestine meth production. Anti-meth measures were predicated onand thus sought to raise-public awareness about the signs of meth production and use. This involved a fundamental reorientation toward the local landscape that centred around methamphetamine. I myself was not immune to this: as I drove away from my meeting with the officer, I noticed a plastic Wal-Mart bag filled with what appeared to be garbage on the side of the road. I wondered, as I drove past, whether it might not have something to do with meth.

\section{Conclusion}

In this article I have examined the impact of recent efforts to curtail the spread of domestic methamphetamine production in the United States on the exercise of police power in a rural community. By heightening regulations on items used in methamphetamine production, anti-meth legislation has reimagined the local landscape of rural communities to accommodate the prerogatives of police power. As a result, the responsibility to police the community has been extended within and beyond the formal domains of law enforcement. Through the anti-methamphetamine legislation, everyone from retail clerks to civic volunteers has been mobilized to take part in the policing of the methamphetamine problem and, by extension, the community more generally.

But even as this approach to the methamphetamine problem takes hold, there are indicators that it may be undergoing another change. As mentioned above, according to DEA statistics, the number of meth-lab incidents in the United States has been declining rapidly since 2004 , in large part thanks to legislation targeting domestic production. This success, however, has inadvertently created an expanded market for foreign production, particularly in Mexico. According to the DEA, the amount of methamphetamine seized at or between points of entry at the US/Mexico border increased roughly $75 \%$ from 2002 to $2004 .^{22}$ As of 2007 , it was still at record levels. ${ }^{23}$ The current

\footnotetext{
Das, "The Act of Witnessing."

DEA, Methamphetamine, http://www.usdoj.gov/dea/concern/meth.html.

National Drug Intelligence Center [NDIC], National Methamphetamine Threat Assessment 2007 (Johnstown: NDIC, 2006).
} 
drug-related violence along the US/Mexico border is symptomatic of this market shift as well. Thus, though recent reports indicate a decline in Mexican meth production, this modulation in the methamphetamine market in the wake of the campaign against domestic production indicates that the supply of methamphetamine has not decreased in tandem with the rise of meth-lab seizures. ${ }^{24}$

This shift in the market is already changing the way methamphetamine is policed and criminalized in the United States. While the typical methamphetamine user is still imagined as white, the typical methamphetamine producer and trafficker is increasingly coming to be seen as Latino/a. ${ }^{25}$ The effect of this shift on rural communities could be profound. Many of these areas have seen a dramatic rise in immigrant populations over the past decade. Baker County is just such an area: it has a burgeoning Latino/a population, primarily from Mexico and Puerto Rico, drawn to the area by the regional poultry industry. At the time of my fieldwork, there was unease in Baker County about this population and a general suspicion that there might be a connection to methamphetamine. Though there was nothing to confirm these suspicions at the time, the growing association between Mexico and the meth trade in national discourse could change that, giving local suspicions a sense of credibility. The association between illegal drugs and minority populations, particularly immigrants, runs deep in the United States. ${ }^{26}$ Thus, it may be that methamphetamine is beginning to follow a more familiar script, as a drug produced outside the United States and trafficked in by others. And as the threat posed by methamphetamine is reimagined, so too will be the responsibilities placed on citizens to police it.

\footnotetext{
Abstract

In the United States, state-based efforts to curtail the spread of methamphetamine ("meth") have targeted domestic producers through heightened regulation of precursor chemicals used in the clandestine meth-production process. This article examines the impact of these efforts on the exercise of police power in a rural community affected by methamphetamine. As the author shows, the targeting of local meth production has incorporated residents of rural communities into the policing process by variously encouraging and requiring them to adopt a new way of perceiving the local landscape, centred around methamphetamine. Under the new legislation, previously benign objects such as cold medicine, batteries, and drain cleaner have been re-signified as objects with criminal potential that residents of rural communities are called upon to police. This has led to the expansion of police power within and beyond the formal domains of law enforcement. Through the targeting of local production, civic volunteers, pharmacists, retail clerks, natural resource officers, and others have been drawn into the policing of the meth problem. This reveals a key dynamic in

NDIC, National Methamphetamine Threat Assessment 2009 (Johnstown: NDIC, 2008).

DEA, Methamphetamine.

D. Musto, The American Disease: Origins of Narcotic Control (New York: Oxford University Press, 1999).
} 
the localization of police power: as police power is localized, the local is reimagined in terms of police power.

Keywords: police, drugs, methamphetamine, crime, United States, ethnography

\begin{abstract}
Résumé
Aux États-Unis, les efforts étatiques qui visent à freiner la propagation des méthamphétamines ont ciblé les producteurs domestiques par la réglementation des produits chimiques utilisés dans le processus de production clandestine de la meth. Cet article examine l'impact de ces mesures sur l'exercice du pouvoir policier dans le contexte d'une communauté rurale affectée par les méthamphétamines. L'auteur démontre comment les opérations qui ciblent la production locale de la meth ont incorporé les résidants des communautés rurales dans le processus policier en les encourageant à adopter une nouvelle façon de percevoir l'univers des méthamphétamines, ou en nécessitant d'eux une telle adoption. Selon les nouvelles réglementations, les objets qui étaient autrefois bénins, tels que les médicaments contre le rhume ou la grippe, les batteries et les nettoyeurs de tuyaux de drainage, sont redéfinis comme des objets potentiellement criminels et la police fait désormais appel à la coopération des résidants des communautés rurales pour contrôler ces substances. Ceci mène à l'expansion du pouvoir policier à l'intérieur et à l'extérieur des domaines formels de l'application de la loi. En ciblant la production locale, les bénévoles civiques, les pharmaciens, les commis de magasin, les agents des ressources naturelles ainsi que d'autres individus sont maintenant impliqués dans la lutte contre les méthamphétamines. Ceci révèle une dynamique importante dans la localisation du pouvoir policier : tandis que le pouvoir policier est localisé, les éléments locaux sont réimaginés en fonction du pouvoir policier.
\end{abstract}

Mots clés: police, drogues, méthamphétamine, crime, États-Unis, ethnographie

William Garriott

Department of Justice Studies

Moody 218 MSC 1205

James Madison University

800 S Main Street

Harrisonburg, VA 22807 USA

garriowc@jmu.edu 